\title{
IMPACT OF ENVIRONMENTAL KNOWLEDGE AND VALUE OF THE ENVIRONMENT ON WORK COMMITMENT
}

\begin{abstract}
Employee commitment is among quality indicators for human resource management. Previous studies on determinants of the commitment level have focused on individual's personal characteristics (age, sex) and organizational circumstances (incentive scheme), ignoring factors related to environmental management. Meanwhile, adoption of environmental orientation in a company affects organizational culture and consequently, human resources. The paper presents the results of the study on the relationship between environmental orientation of a company, environmental knowledge, value of the environment and employee commitment. The main purpose of this study is to examine the relationships between these factors. Therefore, the results enrich findings of the previous studies on employee commitment with knowledge about other factors concerning environmental management. We assume that employee commitment has three multidimensional components namely: affective commitment, continuance commitment, and normative commitment. Questionnaires responses from 433 Polish workers were analyzed confirming the importance of environmental knowledge and awareness of the value of the environment as factors influencing both affective and normative commitment. But the results didn't confirm the correlations with calculative commitment. From the point of view of pro-environmental orientation, it serves the role of moderator relative to the analyzed variables. The managers can use the findings as an argument to support implementation of environmental orientation.
\end{abstract}

Keywords: employee commitment, value of the environment, environmental knowledge.

\section{INTRODUCTION}

Environmental orientation is the "recognition of the legitimacy and importance of the biophysical environment in the formulation of organization strategy, and the integration of environmental issues into the strategic planning process". environment strategy and, what is the most important, in undertakings related to environmental protection. Eco-orientation involves changes in the organizational culture, human resources, skills in managing environmental activity. Its maintenance is dependent on having appropriate financial resources enabling fulfillment of tasks and engagement of the executives in the process of making the organization more environmentally friendly. Moreover, some studies have shown the significance of employee motivation and

${ }^{1}$ Agnieszka Leszczyńska, DSc, PhD, Maria Sklodowska Curie University, Faculty of Economics, Lublin, Pl. M. Sklodowskiej 5, agnieszka.leszczynska@ poczta.umcs.lublin.pl

${ }^{2}$ S.B. Banerjee, Corporate environmentalism: The construct and its measurement, Journal of Business Research 2002, 55(3), 177-191. 
engagement in the implemented undertakings. Studies confirm that commitment facilitates the implementation of pro-environmental efforts ${ }^{3}$. Employee knowledge, concern, system of values are regarded as one of the basic sources of taking eco-friendly activities ${ }^{4}$. Previous empirical studies were devoted to incentives for adopting environmental orientation, its benefits and barriers to implementation. To a minor extent they addressed the questions of employee attitudes or the impact of undertakings promoting eco-friendly approach on their behaviour. Antecedents and outcomes of employee commitment are conceptualised in just a few models ${ }^{5}$. This paper intends to contribute towards the understanding of the antecedents of employee commitment by emphasizing the role of environmental knowledge and value and ecological orientation of organization. Does therefore, eco-orientation (or its absence) induce higher/lower employee commitment? What is the role of employee environmental knowledge and the value of the environment? Subsequent sections of the paper will present the question of work commitment, the research method and empirical findings related to the aforementioned relationships.

\section{RESEARCH PROBLEM}

Commitment has been defined as a lasting wish to retain a relationship which is considered valuable. It is a willingness to make sacrifices in the short term in order to attain long-term benefits. In the research context a distinction is usually made according to whether commitment is attitude-based or behaviour-based. An attitude-based commitment relates to the way in which a party to a relationship views a relationship or this person's intention to commit himself or herself in a particular relationship, while the behaviourbased relationship is more concerned with what one actually does ${ }^{6}$. According to Meyer and Allen ${ }^{7}$, there are three bases of commitment: affective (AOC), normative (NOC), and continuance (COC) organizational commitment. The affective component is strongly linked to the concepts of common values, trust, benevolence and relationships. Affective commitment arises when the committed person has feelings for, identifies himself or herself with and feels psychologically bound to the person he or she has a relationship with. The calculative component is based on the committed person feeling more or less compelled to continue the relationship in question. From organizational point of view this kind of commitment is derived from the perceived costs of leaving the organization such as the loss of economic investments and difficulties in finding a new job. The normative component is concerned with the committed person feeling a more or less moral duty and

\footnotetext{
${ }^{3}$ C.J.C. Jabbour, F.C.A. Santos, Relationships between human resource dimensions and environmental management in companies: proposal of a model, Journal of Cleaner Production, 2008, 16(1), 51-58; D.W.S. Renwick, T. Redman, S. Maguire, Green human resource management: a review and research agenda, International Journal of Management Reviews, 2013, 15(1), 1-14.

${ }^{4}$ E.S.W. Chan, A.H.Y. Hon, An Empirical Study of Environmental Practices and Employee Ecological Behavior in the Hotel Industry, Hospitality, Leisure, Sport, 2014.

${ }^{5}$ B. Shuk, K. Wollard, Employee engagement and HRD: a seminal review of the foundations, Human Resource Development Review, 2010, 9(1), 89-110.

${ }^{6}$ R.T. Mowday, L.W. Porter, R.M. Steers, Employee-organization linkages: The psychology of commitment, absenteeism, and turnover, Academic Press, New York 1982.

${ }^{7}$ J.P. Meyer, T.E. Becker, R. Van Dick, Social identities and commitments at work: Toward an integrative model, Journal of Organizational Behavior, 2006, 27, 665-683.
} 
feeling a responsibility for the relationship to continue ${ }^{8}$. It is based on a perceived obligation to maintain membership in the organization, which is grounded in a sense of morality ${ }^{9}$. Organizational commitment is a psychological state that binds an employee to an organization. While referring to environmental orientation, one should think whether such approach influences employee commitment. Some studies have been conducted regarding the relation of pro-ecological orientation and its relationship with the employees increase of identification and commitment to the organisation, organisational citizenship behaviours and meaningfulness of work ${ }^{10}$. Other studies refer that this orientation could also enhance firms' ability to attract and keep top talent ${ }^{11}$. The literature points out to a gap of theoretical consolidation on how and why environmental orientation impacts on employees. From the literature review a gap related to the relationship between employee commitment and different environmental orientation was identified. Taking into account the results of studies on job satisfaction and eco-orientation ${ }^{12}$, it appears that such a relationship is likely exist. Therefore, it was assumed that:

H1: Employee commitment presents statistically different levels when exposed to different environmental orientation.

Individual employees are instrumental in creating and realizing activities which focused on the environment ${ }^{13}$. Behavior of workers is determined by their attitude and also - by the organizational strategy, culture and relationship with the staff. Personal values explain the choice and taste, and they are extremely difficult to change. A healthy ethics system and moral code ensures grounded decision making and efficient operation of the company ${ }^{14}$. The higher they value the environment and the more extensive their environmental knowledge, the more likely they are to engage in environmental undertakings. Taking into consideration ecological knowledge Huang and Shih ${ }^{15}$ find that the China Steel Corporation - which has applied environmental knowledge circulation process - improves its environmental and financial performance through environmental knowledge creation, environmental knowledge accumulation, environmental knowledge

8 J.P. Meyer, T.E. Becker, C. Vandenberghe, Employee commitment and motivation: A conceptual analysis and integrative model, Journal of Applied Psychology, 2004, 89, 991-1007.

${ }^{9}$ M.U. Taing, B.P. Granger, K.W. Groff, E.M. Jackson, R.E. Johnson, The Multidimensional Nature of Continuance Commitment: Commitment Owing to Economic Exchanges Versus Lack of Employment Alternatives, J. Bus. Psychol., 2011, 26, 269-284.

${ }^{10}$ R.V. Aguilera, D.E. Rupp, C.A. Williams, J. Ganapathi, Putting the S back in corporate social responsibility: a multi level theory of social change in organizations, Academy of Management Review, 2007, 32(3), 836-863.

${ }^{11}$ C.B. Bhattacharya, S. Sen, D. Korschun, Using corporate social responsibility to win the war for talent, MIT Sloan Review, 2008, 49(2), 37-44.

12 A. Leszczyńska, Wiedza i wartości ekologiczne a satysfakcja z pracy, Marketing i rynek 2016, 3, 490-501.; J. Spanjol, W.Y.L. Tam, V. Tam, Employer-employee congruence in environmental values: an exploration of effects on job satisfaction and creativity, Journal of Business Ethics, 2015, 130 (1), 117-130.

${ }^{13}$ S.C. Bolton, R. Kim, K.D. O'Gorman, Corporate social responsibility as a dynamic internal organizational process: A case study, Journal of Business Ethics, 2011, 101(1), 61-74.

${ }^{14} \mathrm{~S}$. Janis, Employees' values orientation in the context of corporate social responsibility, Baltic Journal of Management, 2008, 3(3), 346-358.

${ }^{15}$ P. Huang, L. Shih, Effective environmental management through environmental knowledge management, International Journal of Environmental Science and Technology, 2009, 6 (1), $35-50$. 
sharing, environmental knowledge utilization and environmental knowledge internalization. Moreover, Branzei ${ }^{16}$ find that specialized environmental knowledge increases firms' environmental innovation. The authors suggest that specialized knowledge may be a critical component of environmental performance. It can be ventured that in the case of a pro-environmentally oriented enterprise, the higher the level of such orientation, the greater employee commitment, especially in terms of initiatives related to environmental protection. It was therefore assumed that:

$\mathrm{H} 2$ : There is a relationship between employee environmental knowledge and their commitment.

H3: There is a relationship between the value employees assign to the environment and employee commitment.

\section{METHOD}

A questionnaire presented to employees of selected Polish enterprises served as the research tool. It featured questions concerning the types of knowledge, frequency with which it is broadened, personal values and work commitment. The Likert scale (1-5) was used. Environmental knowledge was taken as declared by the respondent. The value of the environment was evaluated based on the individual concern for the natural environment and care for its condition. Environmental orientation of firms was determined through the analysis of company reports. It was measured by specific pro-environmental activities taken by and within the organization. Orientation was therefore determined using factors, such as e.g. corporate environmental responsibility, the scope of activities promoting environmental protection, funds assigned for environmental protection. Consequently, studied companies were divided into two groups: firms with high or low environmental orientation. Work commitment was determined using its components: affective, normative and calculative commitment. Affective commitment is based on the emotional connection to the organization, an employee identifies him- or herself with problems of the company. Normative commitment was assessed through loyalty to the organization, responsibility towards colleagues, e.g. I believe that one needs to be always loyal to their organization. Continuance (calculative) commitment is related to benefits gained by an employee at the workplace, e.g. The company offers me so many benefits that for the moment I find it unnecessary to look for a new job. Demographics, such as sex, age, position were the control variables.

The research process entailed the following stages:

1. Defining the aim, research scope

2. Compilation of the questionnaire

3. Verification of the questionnaire with a group of 20 employees (working students), questionnaire improvement

4. Sample design

5. The study

6. Compilation of results, drawing the conclusions

${ }^{16}$ O. Branzei, P.D. Jennings, I. Vertinsky, A knowledge-based view of environmental performance in different cultural contexts: Canada, Japan, and China, paper presented at the Academy of Management Conference, Organizations and the Natural Environment Division, Denver, CO, 9-14 August 2002. 
The sample was composed of 433 respondents representing different enterprises, 55\% of whom were women. The group was dominated by employees working as specialists $(55 \%)$, executives $(25 \%)$. Distribution of respondents by type of position is presented in Fig. 1. $25 \%$ of the respondents were under 30 years of age, $34 \%$ were aged $31-40$ and $21 \%$ aged $41-50$.

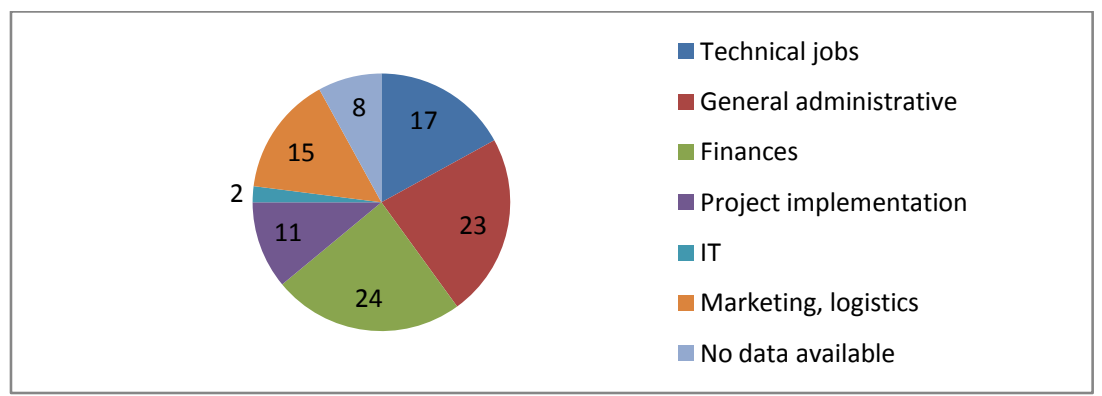

Fig. 1. Respondents by type of position

Source: own study.

\section{RESULTS}

Mean values were compiled in Table 1. According to the results, the fact of having environmental knowledge and average employee commitment exceed the mean value. Respondents ascribed the highest value to the normative commitment (3.9), which indicates a high level of employee responsibility. They are committed to the organization because they find it to be their duty.

Table 1. Descriptive statistics

\begin{tabular}{|l|c|c|}
\hline & Mean & Standard deviation \\
\hline Environmental knowledge & 3,14 & 1,14 \\
\hline COM_AFE & 3,37 & 1,09 \\
\hline COM_CALC & 2,92 & 1,27 \\
\hline COM_NORM & 4,00 &, 97 \\
\hline COM average & 3,46 &, 84 \\
\hline
\end{tabular}

Source: own study

The level of environmental knowledge grows among older employees. Its significance was confirmed by $48 \%$ of respondents aged 51-60 and subsequent $68 \%$ of respondents aged $60+$. The level of this knowledge is higher in male employees (41\%). It is of the highest significance for managerial positions, which was confirmed by $45 \%$ of managers in the sample $(54 \%$ of the respondents in technical positions, $39 \%$ in administrative positions). A significant position of the environment in the hierarchy of values was indicated by $27 \%$ of the respondents. The value ascribed to the environment is higher in men ( $72 \%$ of total responses in that group); in individuals working as managers, $87 \%$. The 
value ranked high among employees aged between 41 and 50 years (80\%) and over 60 years old $(100 \%)$. As far as commitment is concerned, it is age- and position-related (Tab. 2). The same is corroborated by earlier studies ${ }^{17}$. The relationship between sex and work commitment was found to be statistically insignificant. It should be concluded, that the average commitment level grows systematically across consecutive age groups, reaching its peak value in the group aged 50+. The level of this variable also grows in the case of managerial positions $(50 \%)$.

Table 2. Results of Spearman's correlation analysis

\begin{tabular}{|l|l|c|}
\hline \multicolumn{2}{|l|}{} & Commitment \\
\hline Age & Correlation coefficient &, $213^{* *}$ \\
& Significance (bilateral) &, 000 \\
\hline Sex & Correlation coefficient &, 048 \\
& Significance (bilateral) &, 110 \\
\hline Position & Correlation coefficient &, $230^{* *}$ \\
& Significance (bilateral) &, 000 \\
\hline
\end{tabular}

** Correlation is significant at the 0.01 level

Source: own study.

In the examined population, employee commitment was related to the fact of having environmental knowledge to an average degree $r=0.17$ (Tab. 3). The correlation occurs for affective commitment $r=0.15$ and normative commitment $r=0.21$. A low degree relationship was found between knowledge and calculated commitment. This means that environmental knowledge provides no employment alternatives; it fails to generate any new job offers. On the other hand, it leads to higher employee identification in case of environmentally oriented organizations, which may result in the growth in affective commitment.

Table 3. Results of Pearson's correlation analysis environmental knowledge commitment

\begin{tabular}{|l|l|c|}
\hline \multicolumn{2}{|l|}{} & $\begin{array}{c}\text { Environmental } \\
\text { knowledge }\end{array}$ \\
\hline Commitment & Correlation coefficient &, $179^{* *}$ \\
& Significance (bilateral) &, 000 \\
\hline COM_AFF & Correlation coefficient &, $152^{* *}$ \\
& Significance (bilateral) &, 00 \\
\hline COM_CALT & Correlation coefficient &, $097^{* *}$ \\
& Significance (bilateral) &, 001 \\
\hline COM_NORM & Correlation coefficient &, $218^{* *}$ \\
& Significance (bilateral) &, 000 \\
\hline
\end{tabular}

** Correlation is significant at the 0.01 level

Source: own study.

${ }^{17}$ M. Juchnowicz, Zarządzanie przez zaangażowanie, PWE, Warszawa 2010. 
The conducted research confirmed the correlation between the value of the environment and employee commitment (tab. 4). It should be emphasized, however, that only $1 / 3$ of the respondents ascribed significance to that value.

Table 4. Results of Pearson's correlation analysis ecological value - commitment

\begin{tabular}{|l|l|c|}
\hline \multicolumn{2}{|l|}{} & Ecological value \\
\hline Commitment & Correlation coefficient &, $522^{* *}$ \\
& Significance (bilateral) &, 000 \\
\hline COM_AFF & Correlation coefficient &, $497^{* *}$ \\
& Significance (bilateral) &, 00 \\
\hline COM_CALT & Correlation coefficient &, $452^{* *}$ \\
& Significance (bilateral) &, 001 \\
\hline COM_NORM & Correlation coefficient &, $355^{*}$ \\
& Significance (bilateral) &, 013 \\
\hline
\end{tabular}

** Correlation is significant at the 0.01 level

* Correlation is significant at the 0.05 level

Source: own study.

As seen above, there is a statistically significant correlation between the respective types of commitment and the value of the environment. Said value influences organizational decision making processes, course of action as well as time and resources devoted to the same, and consequently employee commitment. Thus, environmental values complement primary values necessary to ensure such commitment, i.e. justice, trust and respect. The greater the concurrence between employee and company values, the deeper the commitment. Therefore, further analysis pertained to companies with or without environmental orientation (Tab. 5-7). It showed similar mean results with respect to commitment in both groups. Obtained values do not differ significantly from each other. The general results show that, there is very little difference in employee commitment when facing different environmental orientation. This is not consistent with previous research that demonstrates the linkage between that orientation and HR practices and outputs ${ }^{18}$. The mean scores differences are quite small. Thus, although the differences are not significant it does not mean that orientation has no influence whatsoever in work commitment.

The t-Student test was performed in the respective groups, while the homogeneity of group variance was confirmed using Levene's test. The significance level indicates that the respective populations have equal variance. The $t$ test was therefore completed for variance equality. The results indicated that hypothesis 0 ought to be rejected $(p<0.05)$. Consequently, the environmentally oriented group varies from the group with no such orientation in terms of commitment.

${ }^{18}$ I. Buciuniene, R. Kazlauskaite, The linkage between HRM, CSR and performance outcomes, Baltic Journal of Management 2012, 7(1), 5-24; J. Shen, Developing the concept of socially responsible international human resource management, International Journal of Human Resource Management 2011, 22(6), 1351-1363; J. Shen, C.J. Zhu, Effects of socially responsible human resource management on employee organizational commitment, International Journal of Human Resource Management 2011, 22(15), 3020-3035. 
Table 5. Mean commitment relative to orientation

\begin{tabular}{|l|c|c|c|c|}
\hline & \multicolumn{2}{|c|}{$\begin{array}{c}\text { Environmental } \\
\text { orientation }\end{array}$} & \multicolumn{2}{c|}{ No environmental orientation } \\
\hline & Mean & $\begin{array}{c}\text { Standard } \\
\text { deviation }\end{array}$ & Mean & Standard deviation \\
\hline Commitment & 3,34 & 0,65 & 3,99 & 0,80 \\
\hline
\end{tabular}

Source: own study.

Table 6. T test on independent samples

\begin{tabular}{|c|c|c|c|c|c|c|c|c|}
\hline & \multicolumn{2}{|c|}{$\begin{array}{c}\text { Levene's } \\
\text { homogeneity } \\
\text { of variance } \\
\end{array}$} & \multicolumn{6}{|c|}{$\mathrm{T}$ test on mean values } \\
\hline & \multirow[t]{2}{*}{$\mathrm{F}$} & \multirow[t]{2}{*}{$\begin{array}{l}\text { Signifi- } \\
\text { cance }\end{array}$} & \multirow[t]{2}{*}{$\mathrm{T}$} & \multirow[t]{2}{*}{$\begin{array}{l}\text { Significance } \\
\text { (bilateral) }\end{array}$} & \multirow[t]{2}{*}{$\begin{array}{c}\text { Mean } \\
\text { difference }\end{array}$} & \multirow{2}{*}{$\begin{array}{l}\text { Standard } \\
\text { error of } \\
\text { difference }\end{array}$} & \multicolumn{2}{|c|}{$\begin{array}{l}95 \% \text { confidence } \\
\text { interval for mead } \\
\text { difference }\end{array}$} \\
\hline & & & & & & & Lower & Upper \\
\hline $\begin{array}{l}\text { Equal variance } \\
\text { assumed }\end{array}$ & 1,353 &, 251 & 2,671 & ,010 & ,65126 & ,24380 &, 160 & 1,142 \\
\hline $\begin{array}{l}\text { No equal } \\
\text { variance } \\
\text { assumed }\end{array}$ & & & 2,920 & ,007 & ,65126 & ,22301 & ,195 & 1,106 \\
\hline
\end{tabular}

Source: own study.

Further studies included an analysis of correlation for the variables of environmental knowledge, environmental value and work commitment in the populations of companies with and without pro-environmental orientation.

Table 7. Pearson correlation coefficient relative to respective populations

\begin{tabular}{|l|c|c|}
\hline & $\begin{array}{c}\text { Environmental } \\
\text { orientation }\end{array}$ & $\begin{array}{c}\text { No environmental } \\
\text { orientation }\end{array}$ \\
\hline Commitment - knowledge &, $059(, 383)$ &,$^{246^{* *}(, 000)}$ \\
\hline Commitment - COM_AFF &, $116(, 083)$ &, $18^{* *}(, 000)$ \\
\hline Commitment - COM_CALT &, $06(, 343)$ &, $155^{* *}(, 000)$ \\
\hline Commitment - COM_NORM &, $139^{*}(, 03)$ &, $234^{*}(, 00)$ \\
\hline Commitment - values & $\mathrm{a}$ &, $113^{* *}(, 009)$ \\
\hline Values - COM_AFF & $\mathrm{a}$ &, $043^{* *}(, 000)$ \\
\hline Values - COM_CALT & $\mathrm{a}$ &, $077^{*}(, 015)$ \\
\hline Values - COM_NORM & $\mathrm{a}$ &, $023^{*}(, 061)$ \\
\hline
\end{tabular}

** Correlation is significant at the 0.01 level

a - due to the low number of indications of environmental significance in this group, the correlation could not be calculated

Source: own study.

The analysis revealed the statistical insignificance of the correlation between commitment and environmental knowledge in non-environmentally oriented companies, 
with the only exception of normative commitment. Employees tend to perceive the obtainment of such knowledge as a form of obligation or duty. No correlation in terms of the value of the environment was observed given the low number of respondents identifying said value as significant in this group. Conversely, in the group of environmentally oriented companies, a statistically significant relationship was identified between environmental knowledge and values on the one hand and employee commitment on the other. Therefore, it can be concluded that pro-environmental orientation serves the role of moderator. It determines the conditions, under which the analyzed correlation may occur by conditionally differentiating the relationships between variables in the studied groups.

\section{SUMMARY}

The level of employee commitment is rightly regarded as an indicator of operational efficiency. It is the key driver of organizational efficiency and workforce performance.

Considering the fact that values influence assessment of employee expectations, they may be regarded as the source of commitment. Personal values influence the process of making decisions in the organization and selection of activities in which employees invest their time and energy ${ }^{19}$, therefore they affect the level of commitment and employee performance (effective commitment). However, in order for them to activate commitment, it is important for employee personal values and organizational values to converge. Building of an organization based on values shared by the employees strengthens affective commitment, and is likely to trigger the effective commitment as well ${ }^{20}$. In light of the obtained results, one should take note of the high incidence of individual respondent indications of environmental value in pro-environmentally oriented companies. The conducted studies partially corroborated the correlation between environmental value and work commitment, as stipulated in hypothesis 3.

Supporting the development of employee knowledge (e.g. by offering trainings) and its use also constitute determinants of the level of work commitment. If the organization fails to use employee knowledge, this leads to decreased job satisfaction and professional fulfillment, and consequently to decreased employee commitment. During the research, hypothesis 2 that assumed existence of a relationship between environmental knowledge and commitment was partly positively verified. Said relationship proved statistically significant in the entire population, as well as in the group of environmentally oriented firms. In particular, the relationship between knowledge and affective and normative commitment was confirmed. In line with the growth of environmental knowledge, employee identification with the organization and the feeling of duty in relation to the organization grows as well.

Environmental orientation of a company is not linked to commitment, which allows to reject hypothesis 1 . Commitment level fails to significantly change as a result of adoption or failure to adopt this orientation. Also, it does not influence the correlation coefficients between the examined variables. This stems from the fact that employees are not offered

${ }^{19}$ B.Z. Posner, Another Look at the Impact of Personal and Organizational Values Congruency, Journal of Business Ethics, 2010, 97.

${ }^{20}$ J. Stankiewicz, M. Moczulska, Wartości jako czynnik warunkujący zaangażowanie pracowników w organizacji (w świetle badań empirycznych), http://zif.wzr.pl/pim/2013_4_1_26.pdf 
any benefits due to adoption of environmental orientation, therefore it does not translate into their level of commitment. To strengthen this level, it would be reasonable to relate more strongly the company's environmental orientation with the value ascribed to the environment by the employees, and with an incentive scheme. The conducted research confirmed that pro-environmental orientation serves the role of moderator relative to the analyzed variables. It is the decisive factor that determines the occurrence (or nonoccurrence) of the correlation by influencing its strength. Our study contributes to management practice by providing evidence that the value of the environment and environmental knowledge are (to some extent) associated with workers' commitment. Managers can use these findings as an argument to support implementation of environmental orientation. On the other hand, it is possible to increase the commitment of employees who value the environment by emphasizing the pro-environmental orientation of eh company and the implementation of various related initiatives.

\section{ACKNOWLEDGEMENTS}

This paper was prepared during an implementation of the project: Competence of specific employee groups in the context of diversity management by innovative enterprises, 2013/09/B/HS4/01307.

\section{REFERENCES}

[1] Aguilera R.V., Rupp D.E., Williams C.A., Ganapathi J., Putting the $S$ back in corporate social responsibility: a multi level theory of social change in organizations, Academy of Management Review, 2007, 32(3), 836-863.

[2] Buciuniene I., Kazlauskaite R., The linkage between HRM, CSR and performance outcomes, Baltic Journal of Management, 2012, 7(1), 5-24.

[3] Banerjee S.B., Corporate environmentalism: The construct and its measurement. Journal of Business Research, 2002, 55(3), 177-191.

[4] Bhattacharya C.B., Sen S., Korschun D., Using corporate social responsibility to win the war for talent, MIT Sloan Review, 2008, 49(2), 37-44.

[5] Bolton S.C., Kim R., O'Gorman K.D., Corporate social responsibility as a dynamic internal organizational process: A case study. Journal of Business Ethics, 2011, 101(1), 61-74.

[6] Branzei O., Jennings P.D., Vertinsky I., A knowledge-based view of environmental performance in different cultural contexts: Canada, Japan, and China, paper presented at the Academy of Management Conference, Organizations and the Natural Environment Division, Denver, CO, 9-14 August 2002.

[7] Chan E.S.W., Hon A.H.Y., An Empirical Study of Environmental Practices and Employee Ecological Behavior in the Hotel Industry. Hospitality, Leisure, Sport, 2014.

[8] Huang P., Shih L., Effective environmental management through environmental knowledge management, International Journal of Environmental Science and Technology, 2009, 6 (1), 35-50. 
[9] Jabbour C.J.C., Santos F.C.A., Relationships between human resource dimensions and environmental management in companies: proposal of a model, Journal of Cleaner Production, 2008, 16(1), 51-58.

[10] Janis S., Employees' values orientation in the context of corporate social responsibility, Baltic Journal of Management, 2008, 3(3), 346-358.

[11] Juchnowicz M., Zarządzanie przez zaangażowanie. PWE, Warszawa 2010.

[12] Leszczyńska A., Wiedza $i$ wartości ekologiczne a satysfakcja z pracy, Marketing i rynek, 2016, 3, 490-501.

[13] Meyer J.P., Becker T.E., Van Dick R., Social identities and commitments at work: Toward an integrative model. Journal of Organizational Behavior, 2006, 27, 665-683.

[14] Meyer J.P., Becker T.E., Vandenberghe C., Employee commitment and motivation: A conceptual analysis and integrative model. Journal of Applied Psychology, 2004, 89, 991-1007.

[15] Mowday R.T., Porter L.W., Steers R.M., Employee-organization linkages: The psychology of commitment, absenteeism, and turnover. Academic Press, New York 1982.

[16] Posner B.Z., Another Look at the Impact of Personal and Organizational Values Congruency. Journal of Business Ethics, 2010, 97.

[17] Renwick D.W.S., Redman T., Maguire S., Green human resource management: a review and research agenda, International Journal of Management Reviews, 2013, 15(1), 1-14.

[18] Shen J., Developing the concept of socially responsible international human resource management, International Journal of Human Resource Management, 2011, 22(6), 1351-1363.

[19] Shen J., Zhu C.J., Effects of socially responsible human resource management on employee organizational commitment, International Journal of Human Resource Management, 2011, 22(15), 3020-3035.

[20] Shuk B., Wollard K., Employee engagement and HRD: a seminal review of the foundations, Human Resource Development Review, 2010, 9(1), 89-110.

[21] Spanjol J., Tam W.Y.L., Tam V., Employer-employee congruence in environmental values: an exploration of effects on job satisfaction and creativity. Journal of Business Ethics, 2015, 130 (1), 117-130.

[22] Stankiewicz J., Moczulska M., Wartości jako czynnik warunkujący zaangażowanie pracowników w organizacji (w świetle badań empirycznych) http://zif.wzr.pl/pim/ 2013_4_1_26.pdf, 2013.

[23] Taing M.U., Granger B.P., Groff K.W., Jackson E.M., Johnson R.E., The Multidimensional Nature of Continuance Commitment: Commitment Owing to Economic Exchanges Versus Lack of Employment Alternatives, J. Bus. Psychol., 2011, 26, 269-284. 


\section{WPLYW WIEDZY EKOLOGICZNEJ I WARTOŚCI ŚRODOWISKA NATURALNEGO NA ZAANGAŻOWANIE W PRACE}

Publikowane uprzednio wyniki badań empirycznych wskazują, że wdrożenie strategii środowiskowej generuje korzyści dla organizacji tj. wzrost udziału w rynku, poprawa wizerunku, poprawa przyszłych wyników finansowych. Dotychczasowe publikacje koncentrują się jednak na finansowych efektach działań proekologicznych. W niewielkim zakresie prowadzone są natomiast badania ich wpływu na zachowania pracowników. Tymczasem wprowadzenie orientacji proekologicznej w przedsiębiorstwie wpływa na kulturę organizacyjną, a przez to na zasoby ludzkie. $Z$ punktu widzenia badania zaangażowania pracowników identyfikacja czynników, które wywierają wpływ na jego poziom pozwala na wyciągnięcie wniosków dotyczących optymalnych działań w zakresie zarządzania zasobami ludzkimi w konkretnej organizacji. W artykule przedstawione zostały wyniki badania zależności pomiędzy orientacją ekologiczną przedsiębiorstwa, wiedzą ekologiczną pracowników, wartością środowiska naturalnego oraz zaangażowaniem pracowników. Próba badawcza objęła grupę 433 osób. Uzyskane wyniki uzupełniają dotychczasowe badania nad zaangażowaniem pracowników o nowe czynniki dotyczące zarządzania środowiskowego. Wyniki badań uzupełniają zatem dotychczasowe badania nad zaangażowaniem pracowników o nowe czynniki dotyczące zarządzania środowiskowego. Potwierdziły one znaczenie wiedzy ekologicznej pracowników oraz wartości środowiska naturalnego dla zaangażowania afektywnego i normatywnego. Negatywnie zweryfikowano natomiast te relacje w odniesieniu do zaangażowania kalkulacyjnego. Orientacja ekologiczna przedsiębiorstwa pełni rolę moderatora, decydując o wystąpieniu (bądź nie) zależności pomiędzy badanymi zmiennymi. Możliwe jest zwiększanie zaangażowania pracowników ceniących wartość środowiska naturalnego poprzez podkreślanie proekologicznej orientacji przedsiębiorstwa oraz realizację inicjatyw w tym obszarze.

Słowa kluczowe: zaangażowanie pracowników, wartość środowiska, wiedza ekologiczna.

DOI:10.7862/rz.2016.hss.69

Przestano do redakcji: wrzesień $2016 r$.

Przyjęto do druku: grudzień 2016 r. 